\title{
Influence of Pollutants on the Bottom Sediment of Sewage Receiving Asa River, Ilorin, Nigeria.
}

\author{
*Ogundiran, Mathew Akinloye and Fawole, Olatunde Olubanjo \\ Environmental Biology Unit, Pure and Applied Biology DepartmentLadokeAkintola University of Technology, \\ Ogbomoso, Nigeria. \\ E-mail of Corresponding Author: - mogundiran@lautech.edu.ng
}

\begin{abstract}
The aim of this study was to evaluate the sediment quality in the Asa River environment, in order to identify areas where sediment contamination could cause ecosystem degradation. Samples were obtained from three different locations and sediment are characterized for grain sizes, total organic matter, total recovery metals such as, lead, nickel, zinc, iron, arsenic, chromium, copper and cadmium. The sampling and processes of analyzed samples were carried out using the analytical methods as described by American Public Health Association (APHA) and sampling were done for a total period of twenty-four months (Between April, 2011 and March, 2013). Sediment sample from sampling site A had very low concentration of metal compared to sites $B$ and $C$. High anthropogenic metal contamination was identified at sampling site $B$ while metal concentration was found to be lower at sampling site $C$. This increased level of metals at sampling sites $B$ and $C$ could be due to an inappropriate use of waters at these two sites and, this contamination could possibly also be toxic for the resident species in case of re - suspension due to overturning. Statistically, there were significance correlations in the concentrations of heavy metals between the three sampling sites and the two seasons of the year. The level of all heavy metals analyzed was relatively higher than the permissible limits as recommended by World Health Organization, Environmental Standards and Regulations Enforcement Agency, and National Industrial Standard. Of all the metals examined, iron, copper and cadmium were found to be the most abundant in Asa River and its tributaries. Therefore, unregulated deposition of anthropogenic wastes into this river should be discouraged.
\end{abstract}

\section{Introduction}

The quality of soil of the aquatic environment plays a major role in determining the fertility of water body. Soil acts as reservoir for nutrients and several biogeo-cycling taken places at bottom and exchange of nutrients takes at bottom water interface. Nutrient could also be derived from the drainage water and mineralization of organic matter. The influence of soil type and nutrients, on the benthos is well known. The role of sediment nutrients is very much useful in determining nutrients of the river ecosystem. Bottom sediment has been described as a long term sink for contaminants and it has also been taken to be shelter for various life forms including both micro and macrozoobenthic organisms. Contaminants in the sediment pose threats to human health, aquatic life and the environment. Pollutants release to surface water from industrial and municipal discharges, atmospheric deposition and polluted runoff from agricultural, urban mining areas can accumulates to environmentally harmful level in sediment.

Heavy metals are intrinsic, natural constituents of our environment. They are generally present in small amounts in natural aquatic environments. Apart from the natural sources, several anthropogenic ones also contribute to metal concentrations in the environment. In recent times, industrial activities have raised natural natural concentration causing serious environmental problems. The biota that inhabits contaminated sites is generally exposed to very high concentrations of these pollutants (Aderinola, et al., 2009). Human may be contaminated by organic and inorganic pollutants associated to aquatic systems by consumption of contaminated fish and other aquatic resident edible species (Dulo, 2008). This fact may be attributed to the capacity of some aquatic organisms to concentrate heavy metals up to $10^{5}$ times the concentration present in the water medium.

The study of the toxic effects and heavy metals in Asa River is more important in comparison with other pollutants due to their non - biodegradability nature, accumulative properties and long biological half lives. With the increased use of wide varieties of metals and petrochemicals in industries coupled with African life style of dumping wastes around indiscriminately, there is now a greater awareness of toxic metal pollution of the environment. Many of these metals tend to remain in the ecosystem and eventually move from one component of the food chain to another (Aderinola, et al., 2009).

In addition, recently in Nigeria, a considerable population growth has taken place, accompanied by a steep increase in urbanization, industrial and agricultural land use, and this has led to a tremendous increase in discharge of a wide range of pollutants to receiving water bodies and this has in-turn caused an undesirable effects on the different components of the aquatic environment (FAO, 1992; Authman, 1998). Furthermore, 
Influence of Pollutants on the Bottom Sediment of Sewage Receiving Asa River, Ilorin, Nigeria.

modern agricultural activities have introduced diverse polluting su62bstances such as organic matter, chemical fertilizers, insecticides, herbicides, effluents into our immediate water bodies. Among factors, essentially affecting quality of the aquatic environment, hydrobionts by-products of different origins and infestation of organisms have a significant place (Authman, 1998).

In Nigeria, Public environmental issues top the agenda at both international and national levels. This has occurred as a result of environmental degradation, environmental deterioration and underdevelopment. The rapid industrialization is also having a direct and indirect adverse effect on our environment. Industrial development manifested due to setting up of new industries or expansion of the pre-existing ones resulting into the generation of industrial effluents, spatially small scale cottage industries which discharge untreated effluents which causes water, sediment and soil pollution. In advanced countries, environmental monitoring agencies are more effective and environmental laws are strictly followed. General environmental quality monitoring is compulsory and the monitoring of the quality of water resources is done on a regular basis (Robson, 2000). As a result of pollution, any abnormal changes in the water quality can easily be detected and appropriate action is taken before the outbreak of epidemics. In contrast, in a developing country like Nigeria, several numbers of legislations exist on the quality assurances of water resources but such legislations are rarely followed and observed. Industrial growth and its associated environmental problems such as water and sediment contamination is fast increasing (Fakayode and Onianwa, 2002; Fakayode, 2005). Therefore, the purpose of this present study was to evaluate the sediment quality at three different sampling sites along the course of Asa River, in order to identify areas where sediment contamination could be responsible for ecosystem degradation.

\section{Materials And Methods}

Bed sediments sampling was done on Asa River in order to evaluate the heavy metal status of the samples from three sampling sites. The methods of collection as proposed by APHA, 1992; Chapman (1992) was used for the collection of the bed sediments and it stated that; at each sampling points, composite samples would be taken (Four sub-samples from four different sampling points) and they would be bulked together in well-labelled polythene bags and the samples would be taken to the laboratory for the subsequent metals and microbial analysis. The collected samples were kept in polythene bags and transported to laboratory as quick as possible. The samples were dried in air under the shadow in natural conditions. Soon after drying, stones and all other hard objects were removed from the samples and the remaining samples were separately grinded in mortar to break up all aggregates or lumps. The samples were sieved with $2 \mathrm{~mm}$ sized sieve which allowed all nutritional important factors to pass through. Dried sediment samples were later digested in $2 \mathrm{ml}$ Anistar (Merck) nitric acid $(70 \%)$ in a block thermostat $\left(80^{\circ} \mathrm{C}\right)$ for 3 to 4 hours until the solutions were clear. The solutions were then made up to $25 \mathrm{ml}$ with double distilled water in $25 \mathrm{ml}$ volumetric flask. Then, the samples were analysed for heavy metals such as, lead, nickel, zinc, iron, arsenic, chromium, copper and cadmium by inductively Coupled Plasma-mass Spectrometry (ICP-MS, model Perkin-Elmer Elan 5000 ) or for nickel by flame or furnace Atomic AbsorptionSpectrophptometer (AAS- Perlin-Elmer $4100 \mathrm{ZL}$ ) because of restriction of the ICPMS, model (Perkin-Elmer Elan 5000) to detect nickel. Statistical analyses were conducted by oneway ANOVA.

\section{Results}

Sediment samples from the three sampling sites were analyzed for heavy metals and the values were subjected to statistical analyzes to ascertain variation that exist between the sampling sites. The values were compared with the permissible limits of the Federal Environmental Protection Agency (NESREA, 2007 and NIS, 2007) for all categories of water bodies that receives effluents. The values presented in Table 1 and 2 and figures 1 to 9 .

The Lead concentration in the sediment samples ranged between $0.01 \mathrm{mg}^{-1}$ and $0.03 \mathrm{mgl}^{-1}$ with a mean value of $0.02 \pm 0.01$ for sampling site A; $6.98 \mathrm{mg} / \mathrm{kg}$ and $8.61 \mathrm{mg} / \mathrm{kgwith}$ a mean value of $7.87 \pm 0.23$ for sampling site $\mathrm{B}$ and $3.52 \mathrm{mg} / \mathrm{kg}$ and $5.80 \mathrm{mg} / \mathrm{kg}$ with a mean value of $5.29 \pm 0.09$ for sampling site $\mathrm{C}$. Nickel of the three sediment samples was in the range of $0.01 \mathrm{mg} / \mathrm{kg}$ and $0.23 \mathrm{mg} / \mathrm{kg}$ with a mean value of $0.06 \pm 0.02$ for site A, $1.58 \mathrm{mg} / \mathrm{kg}$ and $2.51 \mathrm{mg} / \mathrm{kg}$ with a mean value of $2.08 \pm 0.05$ for site $B$ and $0.98 \mathrm{mg} / \mathrm{kg}$ and $1.41 \mathrm{mg} / \mathrm{kg}$ with a mean value of $1.24 \pm 0.03$ for site $C$. The level of Lead in the sediment samples was $4.67 \pm 0.11$ and $4.11 \pm 0.09$ for dry and rainy seasons respectively. Nickel had $1.17 \pm 0.02$ and $1.08 \pm 0.03$ for dry and rainy season respectively. Zinc also recorded $0.01 \mathrm{mg} / \mathrm{kg}$ and $0.08 \mathrm{mg} / \mathrm{kg}$ with a mean value of $0.02 \pm 0.01$ for site $\mathrm{A} ; 0.03 \mathrm{mg} / \mathrm{kg}$ and $0.12 \mathrm{mg} / \mathrm{kgwith}$ mean a value of $0.07 \pm 0.02$ for site $\mathrm{B}$ and $0.04 \mathrm{mg} / \mathrm{kg}$ and $0.08 \mathrm{mg} / \mathrm{kg}$ with a mean value of $0.06 \pm 0.02$ for site $\mathrm{C}$ while this parameter recorded $0.06 \pm 0.02$ for dry season and $0.04 \pm 0.01$ for rainy season. The concentration of Iron was found between $0.20 \mathrm{mg} / \mathrm{kg}$ and $0.38 \mathrm{mg} / \mathrm{kg}$ with a mean value of $0.31 \pm 0.01$ for site $\mathrm{A} ; 16.63 \mathrm{mg} / \mathrm{kg}$ and $22.83 \mathrm{mg} / \mathrm{kg}$ with a mean value of $20.18 \pm 0.16$ for site B; while sampling site C had between $6.06 \mathrm{mg} / \mathrm{kg}$ and $9.11 \mathrm{mg} / \mathrm{kg}$ with a mean value of $8.16 \pm 0.11$, with $10.13 \pm 0.40$ recorded for dry season and $8.91 \pm 0.34$ for rainy season. Arsenic of all the three sampling sites ranged between $0.01 \pm 0.00 \mathrm{mg} / \mathrm{kg}$, 
Influence of Pollutants on the Bottom Sediment of Sewage Receiving Asa River, Ilorin, Nigeria.

$0.80 \pm 0.00 \mathrm{mg} / \mathrm{kgand} 0.54 \pm 0.01 \mathrm{mg} / \mathrm{kgfor}$ sampling site A, Band C respectively with a mean value of $1.29 \pm 0.03 \mathrm{mg} / \mathrm{kg}$; then, in the dry season, the same parameter recorded a mean value of $1.29 \pm 0.03 \mathrm{mg} / \mathrm{kg}$ and $0.10 \pm 0.02 \mathrm{mg} / \mathrm{kg}$ for the rainy season. Chromium ranged between $0.01 \mathrm{mg} / \mathrm{kg}$ and $0.70 \mathrm{mg} / \mathrm{kg}$ for site A with a mean value of $0.04 \pm 0.01$; site $B$ had $11.51 \mathrm{mgl}^{-1}$ and $13.46 \mathrm{mg} / \mathrm{kg}$ with a mean value of $12.53 \pm 0.21 \mathrm{mg} / \mathrm{kg}$; site $\mathrm{C}$ recorded $5.00 \mathrm{mg} / \mathrm{kg}$ and $7.96 \mathrm{mg} / \mathrm{kg}$ with a mean value of $6.97 \pm 0.80 \mathrm{mg} / \mathrm{kg}$; while the dry season recorded $6.74 \pm 0.12 \mathrm{mg} / \mathrm{kg}$ and $6.29 \pm 0.10 \mathrm{mg} / \mathrm{kg}$ for rainy season. Copper also ranged between the value of $0.70 \mathrm{mg} / \mathrm{kg}$ and $0.86 \mathrm{mg} / \mathrm{kg}$ with a mean value of $0.78 \pm 0.00$ for site A; site B had between $4.88 \mathrm{mg} / \mathrm{kg}$ and $6.25 \mathrm{mg} / \mathrm{kg}$ with a mean value of $5.71 \pm 0.06 \mathrm{mg} / \mathrm{kgwhile}$ site $\mathrm{C}$ had between $2.50 \mathrm{mg} / \mathrm{kg}$ and $3.50 \mathrm{mg} / \mathrm{kg}$ with a mean value of $3.07 \pm 0.06 \mathrm{mg} / \mathrm{kg}$; dry and rainy season had the mean value of $3.30 \pm 0.09 \mathrm{mg} / \mathrm{kgand} 3.08 \pm 0.07 \mathrm{mg} / \mathrm{kgrespectively}$. For Cadmium, the range was in the order of $0.01 \mathrm{mg} / \mathrm{kg}$ and $0.07 \mathrm{mg} / \mathrm{kg}$ for sampling site A with a mean value of $0.02 \pm 0.01$, site $B$ had between $0.55 \mathrm{mg} / \mathrm{kg}$ and $1.22 \mathrm{mg} / \mathrm{kg}$ with a mean value of $0.93 \pm 0.00 \mathrm{mg} / \mathrm{kg}$ while site $\mathrm{C}$ had between $0.04 \mathrm{mg} / \mathrm{kgand} 0.94 \mathrm{mg} / \mathrm{kg}$ with a mean value of $0.56 \pm 0.01$.

Table 1: Mean Concentration of Metals in The Sediment Samples from the three Sampling Sites (April, 2011 To March, 2013)

\begin{tabular}{llll}
\hline Parameters (Mg/kg) & Point A & Point B & Point C \\
\hline & & & \\
Lead $(\mathrm{Pb})$ & $0.02 \pm 0.01^{\mathrm{b}}$ & $7.87 \pm 0.23^{\mathrm{a}}$ & $5.29 \pm 0.09^{\mathrm{b}}$ \\
Nickel (Ni) & $0.06 \pm 0.02^{\mathrm{b}}$ & $2.08 \pm 0.05^{\mathrm{a}}$ & $1.24 \pm 0.03^{\mathrm{b}}$ \\
Zinc (Zn) & $0.02 \pm 0.01^{\mathrm{b}}$ & $0.07 \pm 0.02^{\mathrm{a}}$ & $0.06 \pm 0.02^{\mathrm{a}}$ \\
Iron (Fe) & $0.31 \pm 0.01^{\mathrm{c}}$ & $20.18 \pm 0.16^{\mathrm{a}}$ & $8.16 \pm 0.11^{\mathrm{ab}}$ \\
Arsenic (As) & $0.01 \pm 0.00^{\mathrm{a}}$ & $0.80 \pm 0.00^{\mathrm{b}}$ & $0.54 \pm 0.01^{\mathrm{a}}$ \\
Chromium (Cr) & $0.04 \pm 0.01^{\mathrm{b}}$ & $12.53 \pm 0.21^{\mathrm{a}}$ & $6.97 \pm 0.80^{\mathrm{c}}$ \\
Cadmium (Cd) & $0.02 \pm 0.01^{\mathrm{a}}$ & $0.93 \pm 0.00^{\mathrm{b}}$ & $0.56 \pm 0.01^{\mathrm{bc}}$ \\
\hline
\end{tabular}

*Mean of parameter in the same row having different superscripts are significantly different $(\mathrm{P} \leq 0.05)$

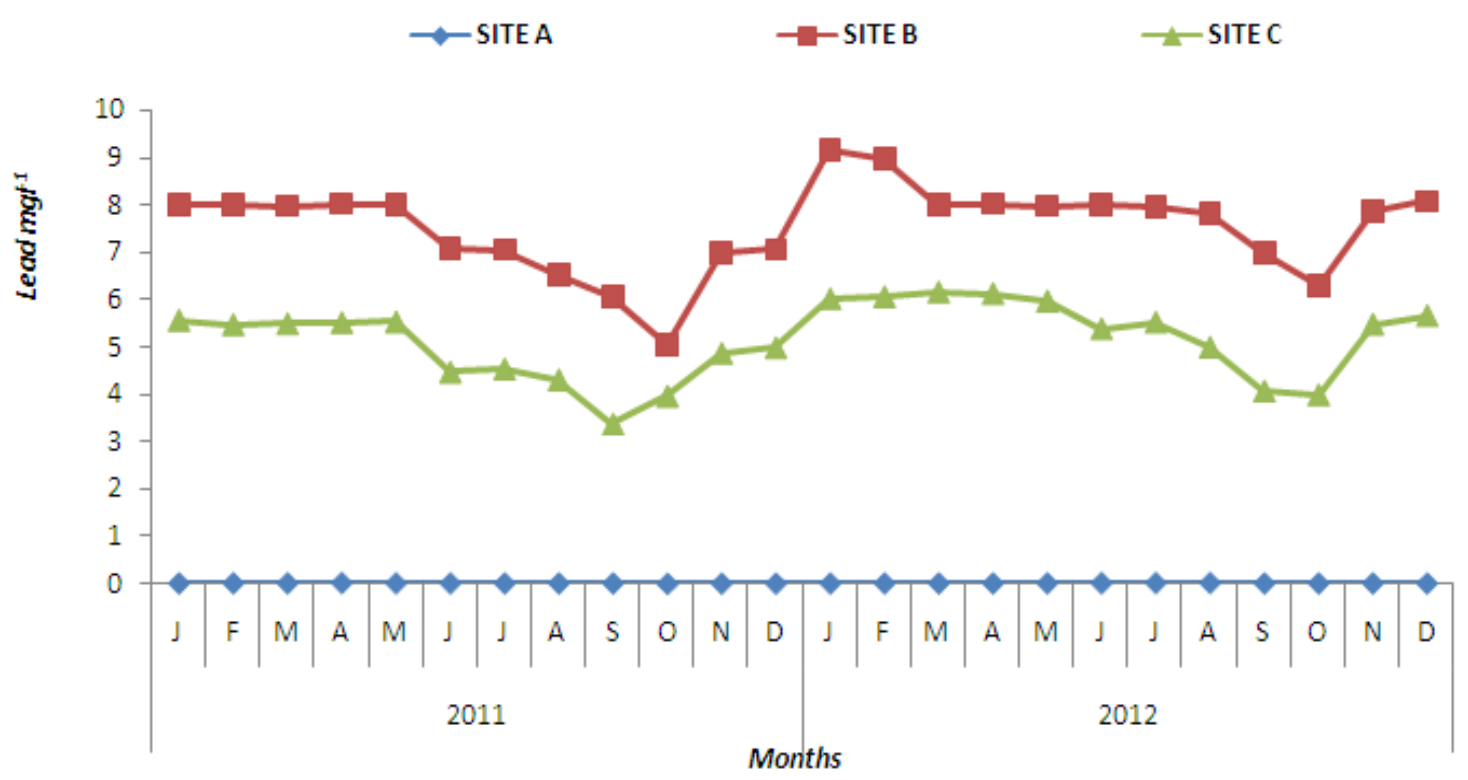

Figure 1: Mean Monthly Variations of Lead in Sediment from the three Sampling Sites 
Influence of Pollutants on the Bottom Sediment of Sewage Receiving Asa River, Ilorin, Nigeria.

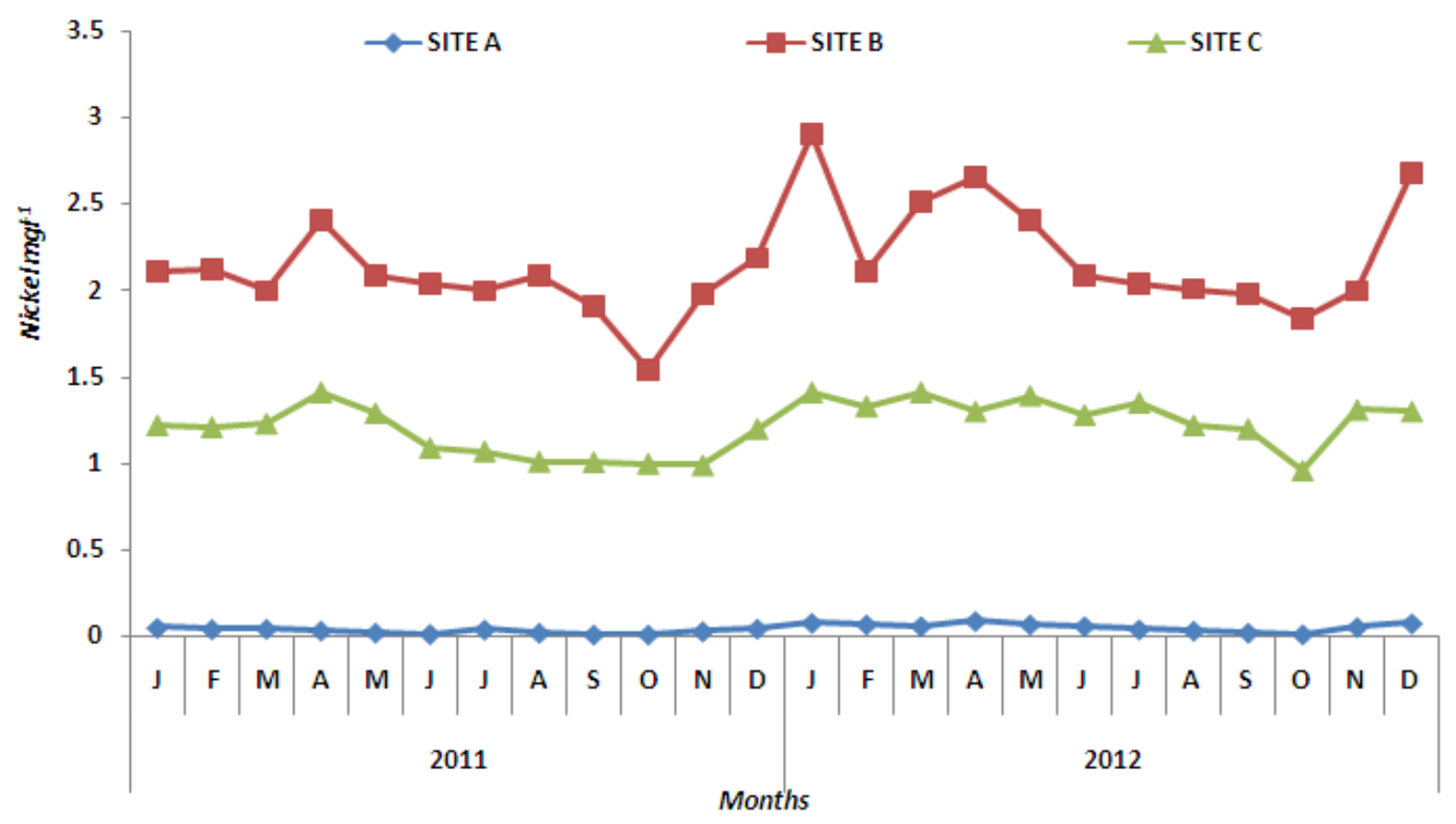

Figure 2: Mean Monthly Variations of Nickel in Sediment from the three Sampling Sites

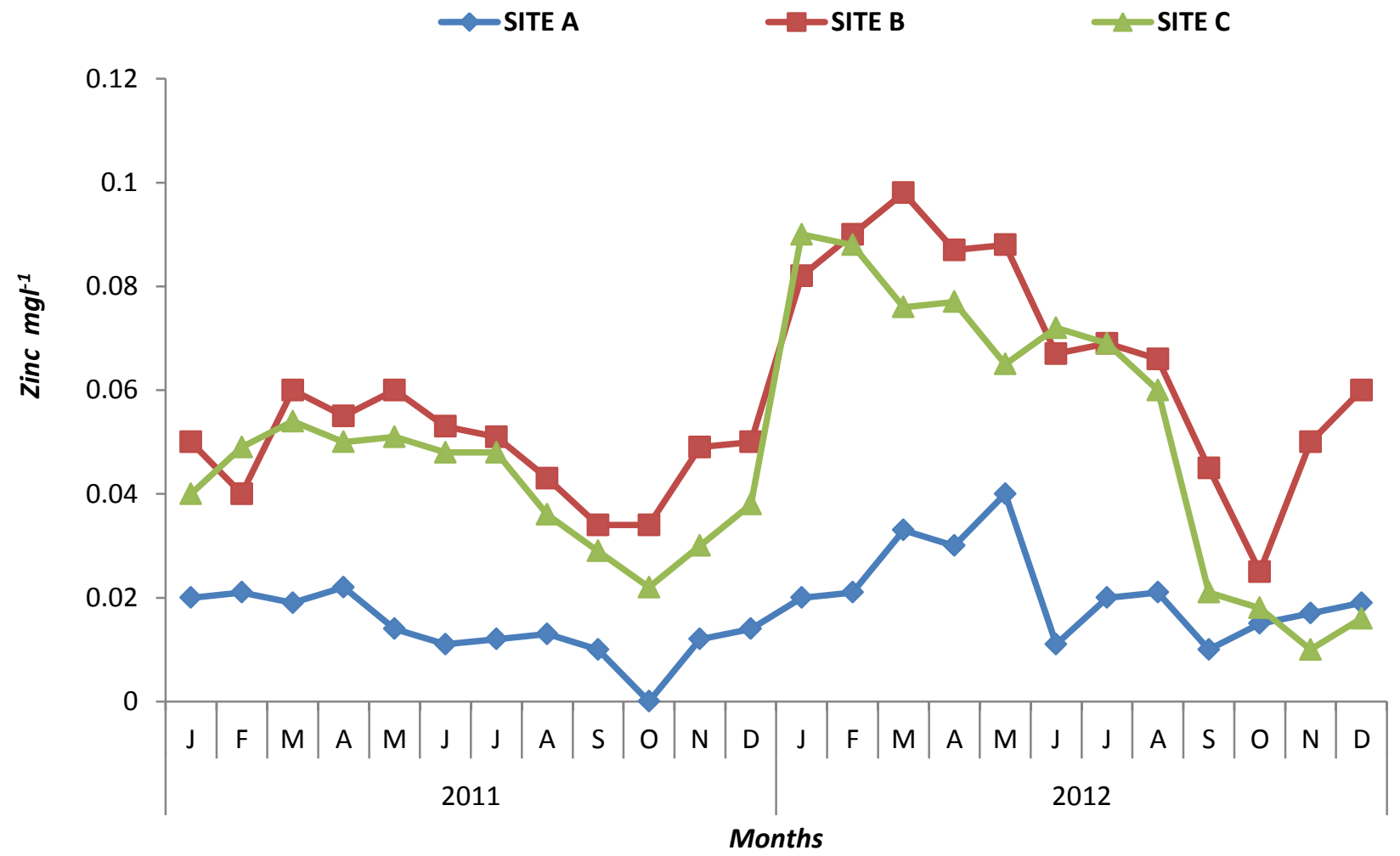

Figure 3 : Mean Monthly Variations of Zinc in Sediment from the three Sampling Sites 


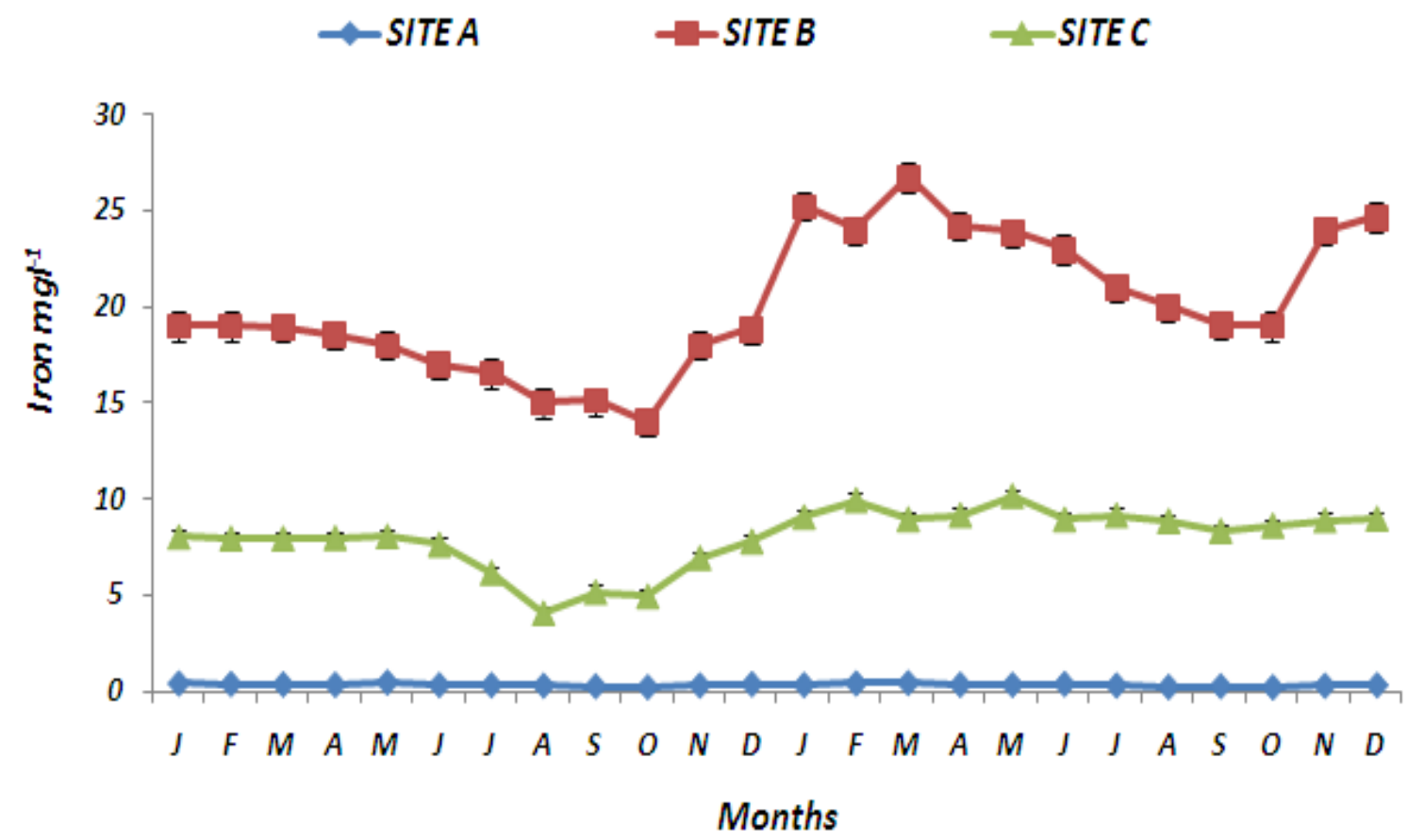

Figure 4: Mean Monthly Variations of Iron in Sediment from the three Sampling Sites

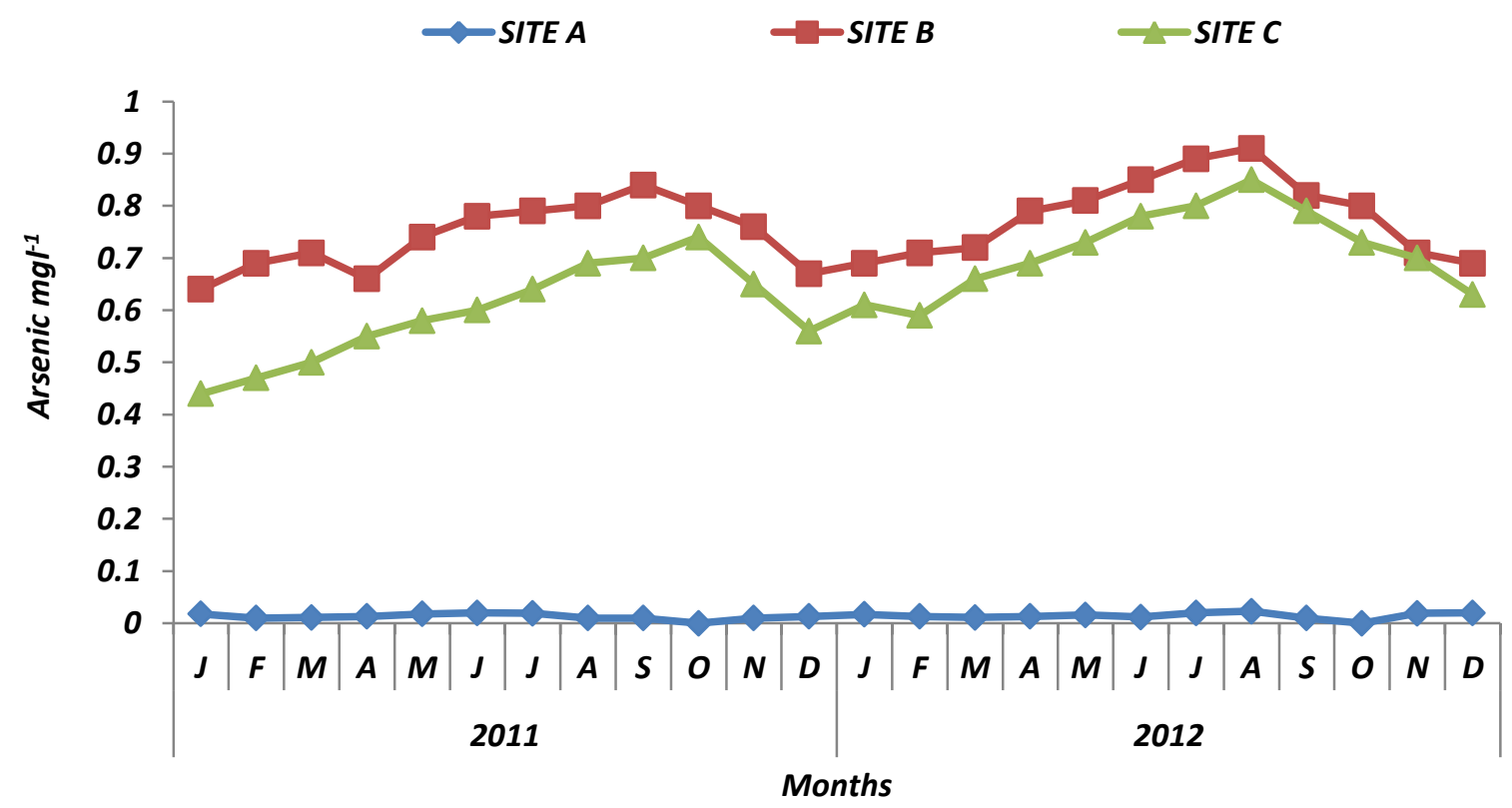

Figure 5: Mean Monthly Variations of Arsenic in Sediment from the three Sampling Sites 


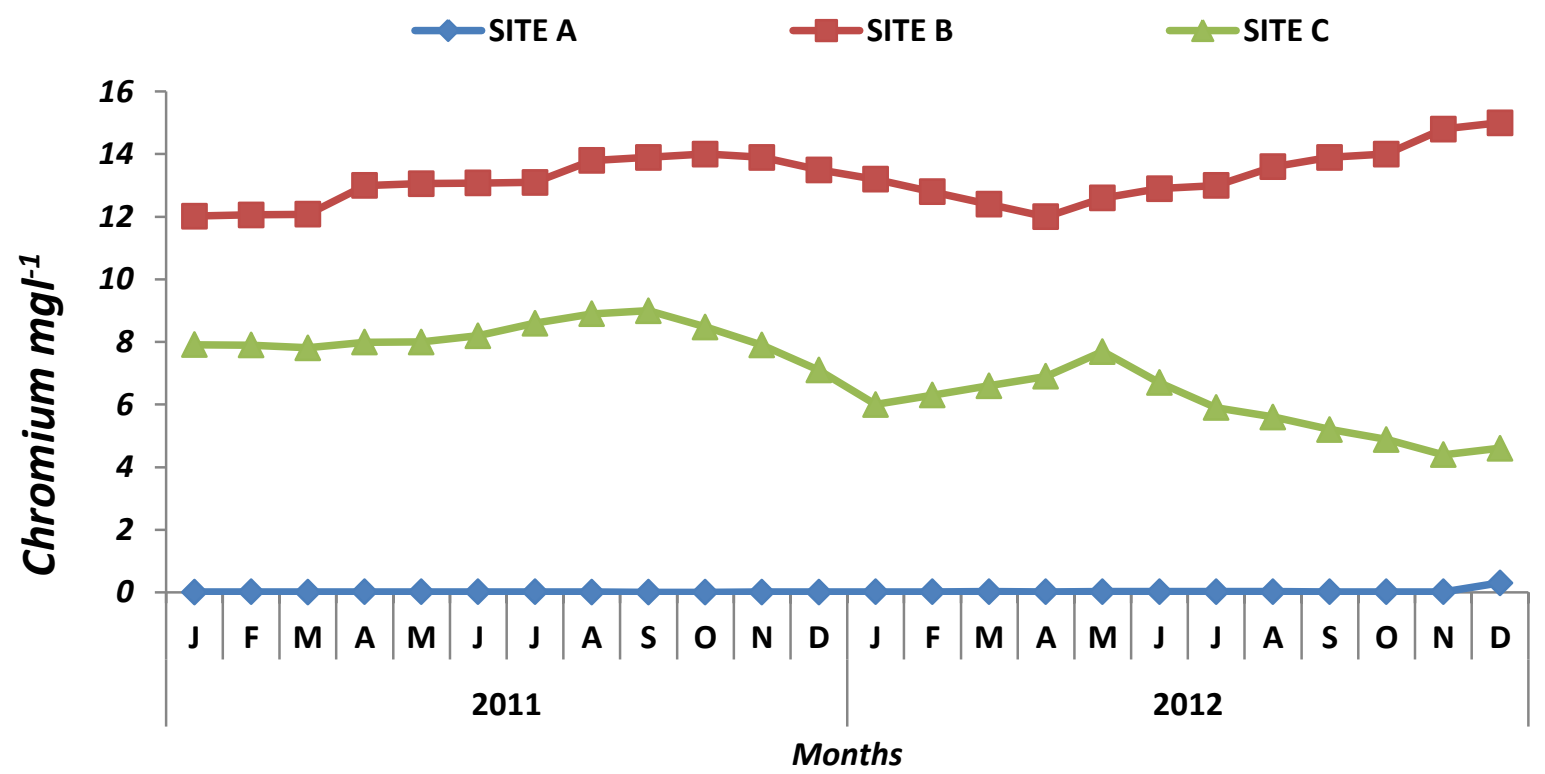

Figure 6: Mean Monthly Variations of Chromium in Sediment fromthe three Sampling Sites

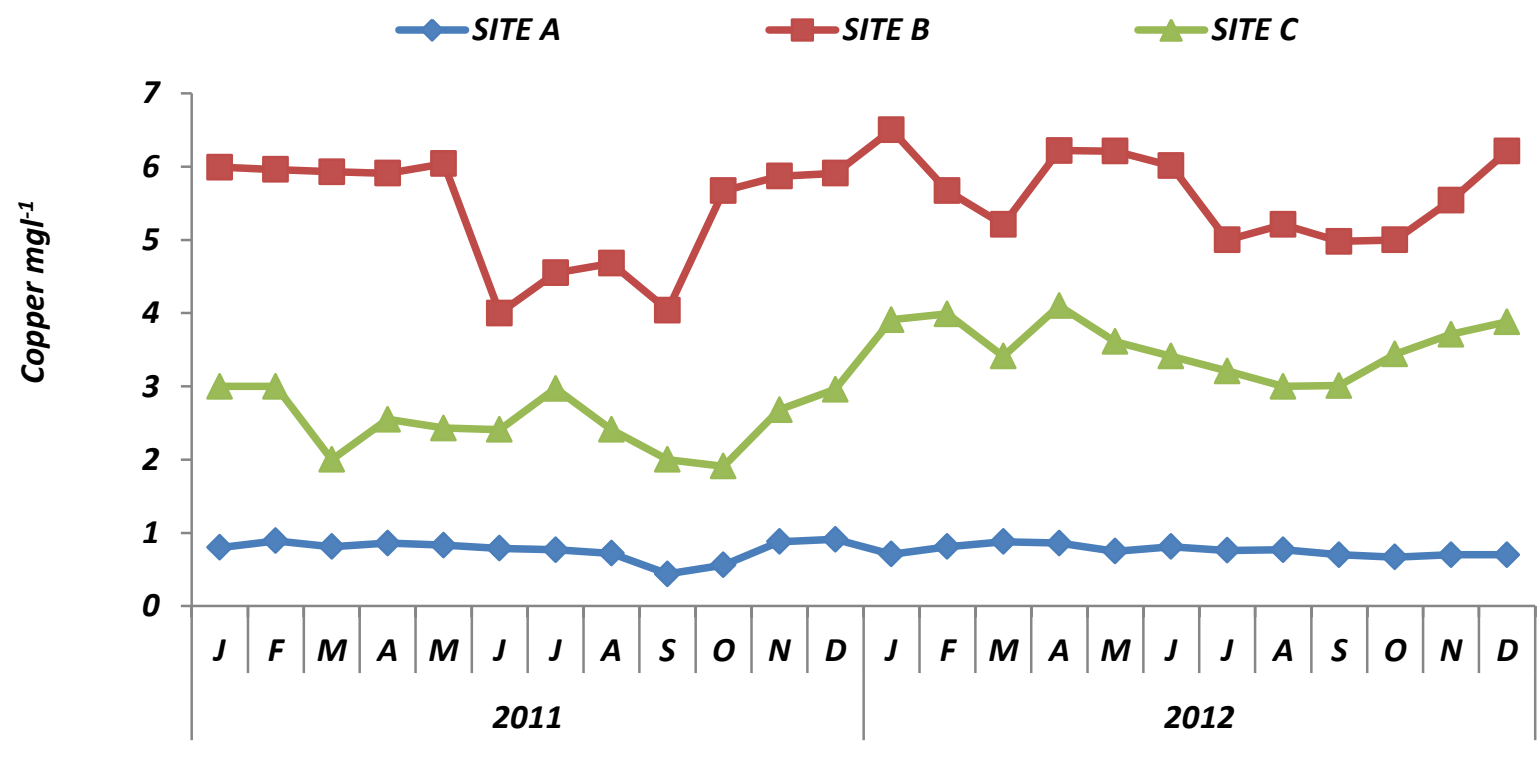

Months

Figure 7: Mean Monthly Variations of Copper in Sediment from the three Sampling Sitres 


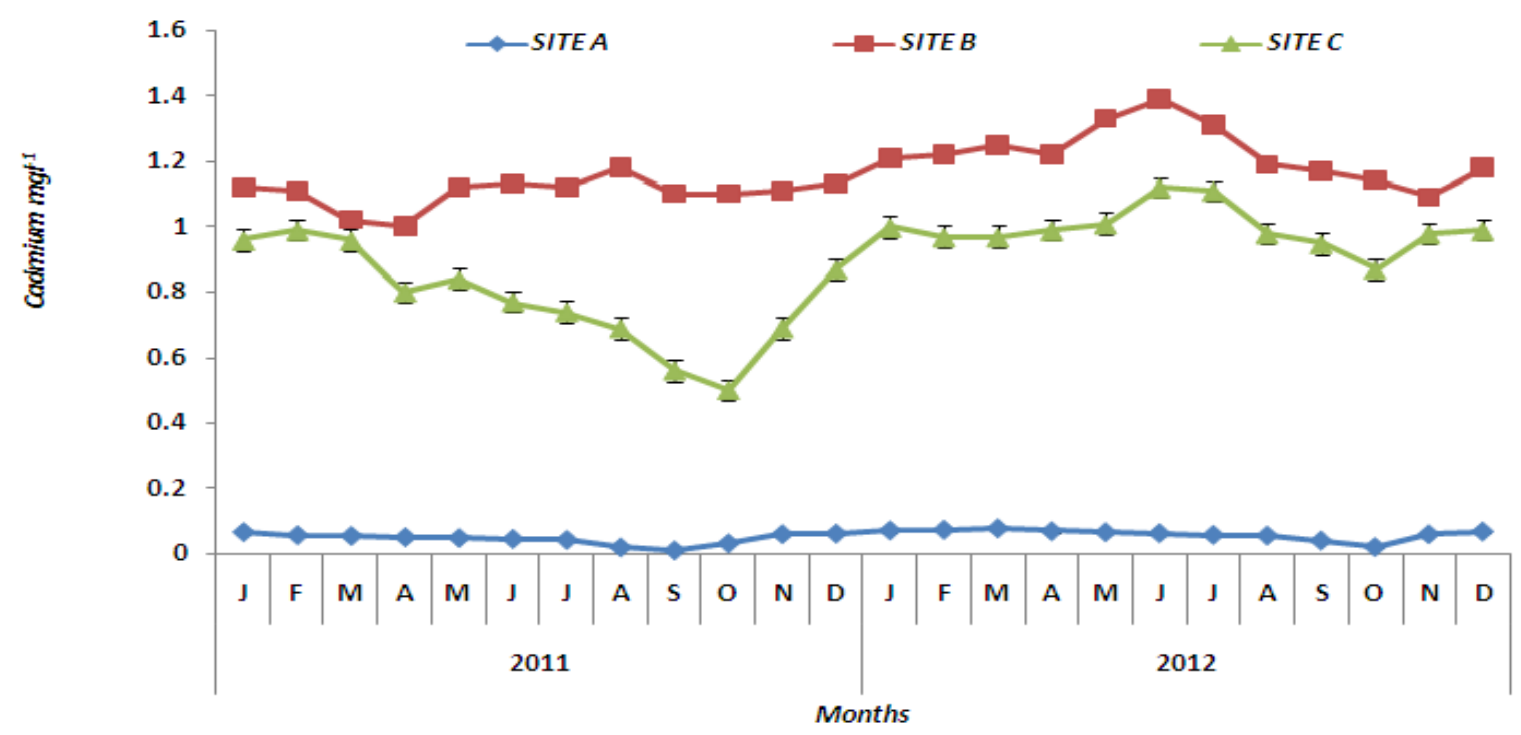

Figure 8: Mean Monthly Variations of Cadmiun in Sediment from the three Sampling Sites

TABLE 2: MEAN CONCENTRATION OF METALS IN THE SEDIMENT SAMPLES COLLECTED IN THE DRY AND RAINY SEASONS (April, 2011 to March, 2013)

\begin{tabular}{|lcc|}
\hline $\begin{array}{l}\text { PARAMETERS } \\
(\mathrm{mg} / \mathrm{kg})\end{array}$ & $\begin{array}{c}\text { DRY SEASON } \\
\text { (October - March) }\end{array}$ & $\begin{array}{c}\text { RAINY SEASON } \\
\text { (April - September) }\end{array}$ \\
\hline Lead (Pb) & $4.67 \pm 0.11^{\mathrm{b}}$ & $4.11 \pm 0.09^{\mathrm{a}}$ \\
\hline Nickel (Ni) & $1.17 \pm 0.04^{\mathrm{a}}$ & $1.08 \pm 0.03^{\mathrm{a}}$ \\
\hline Zinc (Zn) & $3.45 \pm 0.01^{\mathrm{a}}$ & $2.55 \pm 0.01^{\mathrm{b}}$ \\
\hline Iron (Fe) & $10.13 \pm 0.40^{\mathrm{a}}$ & $8.91 \pm 0.34^{\mathrm{b}}$ \\
\hline Arsenic (As) & $1.29 \pm 0.03^{\mathrm{a}}$ & $1.10 \pm 0.02^{\mathrm{a}}$ \\
\hline Chromium (Cr) & $7.21 \pm 0.12^{\mathrm{a}}$ & $6.29 \pm 0.10^{\mathrm{b}}$ \\
\hline Copper (Cu) & $3.30 \pm 0.09^{\mathrm{a}}$ & $3.08 \pm 0.07^{\mathrm{a}}$ \\
\hline Cadmium (Cd) & $1.98 \pm 0.06^{\mathrm{a}}$ & $1.23 \pm 0.05^{\mathrm{a}}$ \\
\hline
\end{tabular}

*Mean for the same parameter in the same row having different superscripts is significantly different $(P \leq 0.05)$

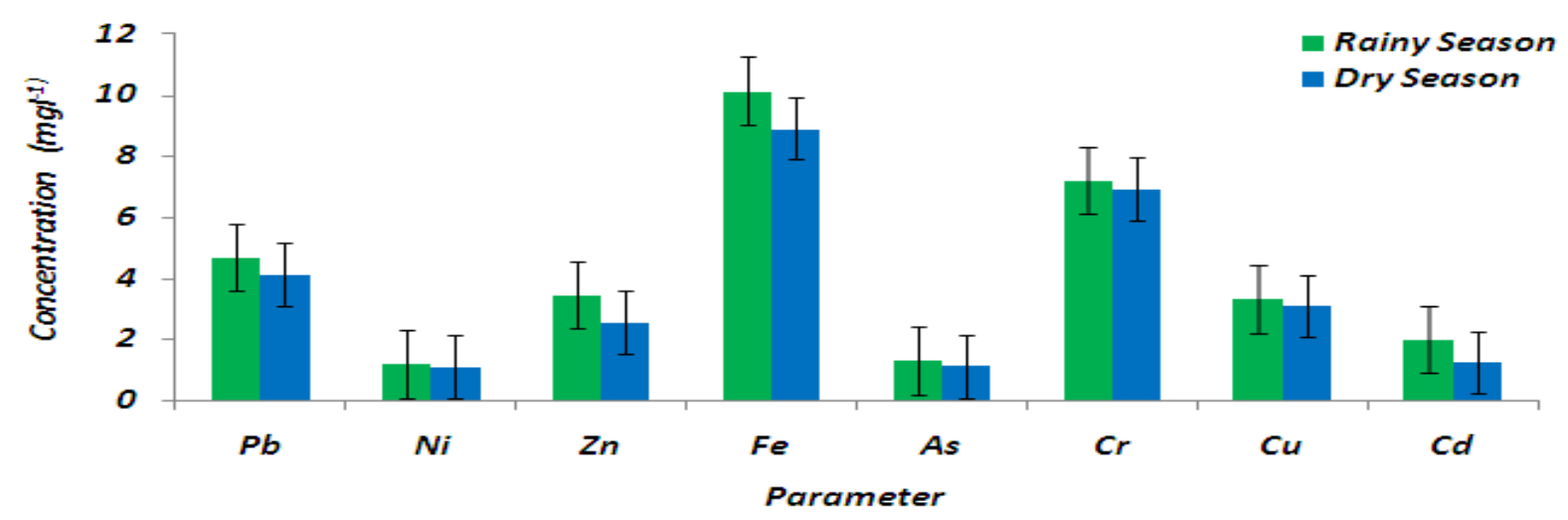

Figure 9: Seasonal Variations of Metals of the Sediment Samples from the three Sampling Sites 


\section{Discussion}

The results of the selected eight heavy metals from the superficial sediment of the three sampling sites of the Asa River revealed that all the analyzed metals were present at level that greatly exceeded the permissible level for all categories of waters. Low concentration of metals were recorded at site A while they was found to be high at both site B and C, and this could be attributed to heavy discharge of industrial effluent into sites B and $\mathrm{C}$. The level of all heavy metals analyzed was relatively higher than the permissible level as recommended by NESREA, (1991), WHO, (2011) and NIS, (2007). Of all the metals examined, iron, copper and cadmium were found to be the most abundant in Asa River and its tributaries. This is in conformity to the submission of Asaolu et al., (1997); Nwajei and Gagophien, (2000). The same level of iron was reported in their work on the application to sediments from lithoral ecosystems on Southern Spain's Atlantic Coast, where iron was found to be abundant, reason which was attributed to high pyrite $\left(\mathrm{FeS}_{2}\right)$ content beneath the Iberian pyrite belt. Variation observed in the metals distribution from Asa River sediment could be attributed to environmental contents of the different areas in the vicinity of the river in question, such as, activities around the studied area, population density, traffic volume, domestic and municipal disposal, sewage effluents, atmospheric fall-out, natural origin and substantial contribution from industrial premises. The concentrations of these metals were found to be higher in the dry season when compared to rainy season and this may be attributed to high pollution load usually experienced during the dry season of the year. This study has confirmed that sediment is important hosts for toxic metals. It has been shown that sediment permit the detection of heavy metals that may be either absent or in low concentration in the water column.

\section{Conclusions}

The continuous increase in heavy metal contamination of these water bodies is a cause for concern, as these metals have the ability to bioaccumulate in the tissues of various biota, and may also affects the distribution and density of benthic organisms, as well as the composition and diversity of population within the community. Therefore, unregulated disposal of wastes into the environment should be discouraged with strict vigilance.

\section{Acknowledgement}

The authors would like to give a vote of thanks to the Central Research Laboratory of LadokeAkintola University of Technology, Ogbomoso, Nigeria for the supply of human and material resources during the period of sample analyses.

\section{References}

[1]. Aderinola, O. J., Clarke, E. O., Olarinmoye, O. M., Kusemiju, V and Anatekhai, M. A. (2009): Heavy Metals in Surface Water, Sediments, Fish and Perwinkles of Lagos Lagoon. American-Eurasian Journal of Agriculture and Environmental Sciences, 5 (5): 609-617

[2]. Asaolu, S. S., Ipinmoroti, K.O. Olaofe, O. and Adeeyinwo, C.E. (1997): Seasonal variation in heavy metal distribution in sediments from Ondo State Coastal area. Ghana J. Chem., 3:11-14.

[4]. APHA (1992): American Public Health Association. Standard methods for the examination of water and waste water 19th edition. Pp472

[5]. Authman, M. M. N. (1998): A study on freshwater pollution and its effects on zooplankton and fish Oreochromisniloticus in Shanawan drainage canal at Almay, Al-Menoufeya Province, Egypt. Ph.D Thesis. Faculty of Science, Al-Menoufeya Univ., Egypt.

[6]. Chapman, D. (1992): Water quality assessment, Chapman and Hall, London

[7]. Dulo, S. O. (2008): Determination of Some Physico-chemical parameters of the Nairobi River, Kenya. J. Appl Sci. Environ. Mangt. 12 (1) $57-67$

[8]. FAO. (1992): CROPWAT: a computer program for irrigation planning and management. M. Smith. Irrigation and Drainage Paper 46. Rome.

[9]. Fakayode, S. O. and Onianwa, P. (2002): Heavy metal contamination of Soil, and Biaccumulation in Guniea Grass (Panicum Maximum) around Ikeja Industrial Estate, Lagos, Nigeria. Journal of Environmental Geology 43(2): 145-150.

[10].

[11]. Fakayode, S.O. (2005). Impact assessment of industrialeffluent on waterquality of the receiving Alarostream in Ibadan, Nigeria. J. Ajeam-Ragee, 10: 1-13.

[12]. NESREA, (1991): Effluent discharge Limitation. S. 1.8 National environment protection agency.

[13]. NESREA, (2007): National Environmental Standards and Regulations Enforcement Agency (establishment) act, 2007 
[14]. NIS (Nigerian Industrial Standard), (2007): Nigerian Standard for Drinking Water Quality. NIS554:2007, $\quad$ ICS $\quad$ 13.060.20, Approved by the Standard Organization of Nigeria (SON) Governing Council,pp;14 - 18

[15]. Nwajei, G. E. and Gagophien, P. O. (2000): Distribution of heavy metals in the sediments of Lagos Lagoon, Pak. J. Sc. Ind. Res. 43:338-340.

[16]. Robson, B. J. (2000): 'Role of residual biofilm in the recolonization of rocky intermittent streams by benthicalgae', Marine and Freshwater Research 51:724-32.

[17]. WHO, (World Health organization) (1988): International standards for drinking water $3^{\text {rd }}$ edition.World health organization, Geneva.

[18]. WHO (World Health Organization), (2011): Guideline for Drinking Water Quality. $4^{\text {th }}$ edn., NLM Classification: WA 675, World Health Organization, Geneva, Switzerland, pp:307-433, ISBN: 9789241548151. 